\title{
Impact on mother, fetus and newborn in case of varicella in pregnancy
}

\author{
Impactul asupra mamei, fătului şi nou-născutului în cazul varicelei la gravidă \\ Ioana Veronica GRĂJDEANU ${ }^{1}$, Ana Maria Alexandra STĂNESCU ${ }^{1}$, \\ Cristian ŞTEFANI ${ }^{1}$, Gina GHEORGHE ${ }^{2}$, Camelia Cristina DIACONU ${ }^{1,2}$ \\ ${ }^{1}$ Universitatea de Medicină şi Farmacie „Carol Davila“, Bucureşti, România \\ ${ }^{2}$ Spitalul Clinic de Urgenţă, Bucureşti, România
}

\begin{abstract}
A wide range of infectious diseases can occur during pregnancy, clinical presentation and course during pregnancy may be altered due to a maternal cell immune disorder. Some infectious diseases can lead to serious consequences for the mother or the fetus, including congenital malformations. It is very important to know in detail the clinical presentation, the course of the disease, the management but also the maternal and fetal risks especially in the case of congenital varicella syndrome, the mother's varicella-zosterian pneumonia and neonatal varicella infection.
\end{abstract}

Keywords: congenital varicella syndrome, varicella-zoster virus pneumonia, neonatal varicella

\section{- REZUMAT}

O serie largă de boli infecțioase pot să apară în timpul sarcinii, prezentarea clinică şi evoluția lor în timpul gestației putând fi modificate din cauza unei dereglări a imunității celulare materne. Unele boli infecțioase pot duce la consecințe grave pentru mamă sau pentru făt, inclusiv malformații congenitale. Este foarte importantă cunoaşterea în detaliu a prezentării clinice, a evoluției bolii, a managementului, dar şi a riscurilor materne şi fetale, în special în cazul sindromului congenital de varicelă, pentru pneumonia cu virusul varicelo-zosterian a mamei şi pentru infecția neonatală cu virus varicelo-zosterian.

Cuvinte cheie: sindrom congenital de varicelă, pneumonie cu virus varicelo-zosterian, varicelă neonatală

\section{INTRODUCERE}

Sindromul congenital de varicelă, pneumonia cu virusul varicelo-zosterian a mamei şi infecţia neonatală cu virus varicelo-zosterian sunt asociate cu morbiditate gravă maternă şi fetală şi, nu rareori, cu mortalitate. Cu toate acestea, vaccinarea împotriva virusului varicelo-zosterian poate preveni boala; administrarea de imunoglobulină înainte de dezvoltarea erupţiilor cutanate, cu sau fără medicamente antivirale, poate modifica progresia bolii (1).

Natura extrem de contagioasă a virusului varicelo-zosterian stă la baza epidemiilor care se răspândesc cel mai adesea în şcoli. Titrurile virale înalte se găsesc în veziculele caracteristice varicelei; astfel, în ciuda riscului asociat mai scăzut, transmiterea virală poate apărea, de asemenea, prin contact direct cu aceste vezicule (2). În climatul temperat, varicela apare cel mai 
frecvent la sfârşitul iernii şi la începutul primăverii. Înainte de posibilitatea vaccinării, $90 \%$ dintre persoanele aflate în zone climatice temperate ar fi avut o infecţie primară (3).

La sfârşitul celei de-a doua faze viremice, apar simptome cum ar fi: cefalee, febră şi stare generală de rău, apoi urmează pruritul şi o erupţie cutanată maculopapulară, care devine veziculară, urmând să apară cruste aproximativ cinci zile mai târziu. Pacientul este contagios cu două zile înainte de apariţia erupţiei până la apariţia crustei veziculelor. Infecţia primară asigură, în general, imunitate pe toată durata vieţii (1).

Infecţiile cu varicelă în timpul sarcinii pot determina mai multe scenarii clinice care sunt asociate cu complicaţii de o severitate variabilă, în funcţie de imunitatea maternă faţă de virus şi de momentul infecţiei, manifestările clinice ale mamei şi ale fătului fiind variate (4).

Avortul spontan nu a fost asociat cu varicela în primul trimestru de sarcină, însă transmiterea la făt înainte de săptămâna a 24-a de sarcină a fost detectată serologic la $24 \%$ dintre cazuri (5). Restricţia de creştere intrauterină apare în aproximativ $23 \%$ dintre cazuri, iar greutatea mică la naştere apare în majoritatea cazurilor (6). Există posibilitatea naşterii premature, iar rata crescută de mortalitate şi morbiditate a fost asociată cu prezenţa sindromului congenital de varicelă, pneumonia cu virusul varicelo-zosterian şi varicela neonatală (7).

\section{Herpes zoster}

Herpes zoster este cauzat de reactivarea unei infecţii latente a virusului când mama este seropozitivă, de obicei nu există viremie sau infecţie transplacentară, exceptând herpesul zoster generalizat. Herpes zoster în timpul sarcinii nu este asociat cu risc pentru mamă sau făt, terapia sistemică cu un analog nucleozidic sau cu o imunoglobulină nefiind necesară (8). Se recomandă tratamentul intravenos cu aciclovir $10-20 \mathrm{mg} / \mathrm{kg}$ de 3 ori pe zi în prezenţa: herpes zoster în dermatita extensivă, herpes zoster oticus, herpes zoster oftalmicus sau herpes zoster hemoragic (9).

\section{Expunerea unei femei gravide seronegative fără manifestări ale bolii}

Multe aspecte trebuie luate în considerare în cazul unei expuneri semnificative la virus. Contactul familial, în aceeaşi casă, cu o persoană care are varicelă sau herpes zoster, contactul direct (mai mult de 5 minute cu o persoană care are varicelă sau herpes zoster nepansat), contactul în aceeaşi încăpere (mai mult de 15 minute) cu un pacient care suferă de varicelă sau her-

TABELUL 1. Prezentarea posibilelor scenarii ale varicelei la gravidă, făt şi nou-născut

\begin{tabular}{|c|c|c|c|}
\hline Afecțiune & Transmitere & Risc & Tratament \\
\hline $\begin{array}{l}\text { Herpes zoster în } \\
\text { sarcină }\end{array}$ & $\begin{array}{l}\text { Fără viremie, nu se } \\
\text { transmite transplacentar } \\
\text { (excepţie - herpes zoster } \\
\text { generalizat) }\end{array}$ & $\begin{array}{l}\text { Fără risc matern sau } \\
\text { fetal }\end{array}$ & $\begin{array}{l}\text { Tratamentul sistemic doar dacă apare } \\
\text { herpes zoster în derma ă ₹xtensivă, } \\
\text { herpes zost } \\
\text { oster? } \\
\text { a\$円micus, sau herpes zoster hemoragic } \\
\text { (în aceste cazuri se recomandă aciclovir } \\
\text { intravenos } 10-20 \mathrm{mg} / \mathrm{kg} \text { de } 3 \text { ori pe zi) }\end{array}$ \\
\hline $\begin{array}{l}\text { Expunerea unei } \\
\text { femei gravide } \\
\text { seronegative fără } \\
\text { manifestări ale bolii }\end{array}$ & $\begin{array}{l}\text { Expuner a ătila } \\
\text { virus }\end{array}$ & $\begin{array}{l}\text { Expunerea la } \\
\text { imunoglobulină nu } \\
\text { produce risc fetal }\end{array}$ & $\begin{array}{l}\text { În caz de seronega at@ se recomandă } \\
\text { vaccinarea în primele } 96 \text { de ore de la } \\
\text { expunere cu o doză i.v. de } 1 \mathrm{ml} / \mathrm{kg}\end{array}$ \\
\hline $\begin{array}{l}\text { Varicela } \\
\text { necomplicată la } \\
\text { gravidă }\end{array}$ & Expunere la virus & $\begin{array}{l}\text { Pentru a evita anumite } \\
\text { riscuri ar trebui } \\
\text { efectuată operaţie } \\
\text { cezariană }\end{array}$ & $\begin{array}{l}\text { În cazurile necomplicate - aciclovir oral } \\
800 \mathrm{mg} \text {, de } 5 \text { ori/zi }\end{array}$ \\
\hline $\begin{array}{l}\text { Sindromul } \\
\text { congenital de } \\
\text { varicelă }\end{array}$ & $\begin{array}{l}\text { Expunerea maternă la } \\
\text { virus - varicela la gravidă - } \\
\text { transmitere transplacentară } \\
\text { la făt }\end{array}$ & $\begin{array}{l}\text { Malformaţii ale mai } \\
\text { multor sisteme sau } \\
\text { ţesuturi sau organe }\end{array}$ & aciclovir intravenos $(10-15$ mg/kg/zi, \\
\hline $\begin{array}{l}\text { Maternal Varicela } \\
\text { Pneumonia }\end{array}$ & Expunere la virus & $\begin{array}{l}\text { Poat } \\
\text { ven ţa }\end{array}$ & aciclovir intravenos $(10-15$ mg/kg/zi, \\
\hline Varicela neonatală & $\begin{array}{l}\text { Transplacentar, ascendent } \\
\text { sau prin tractul respirator } \\
\text { neonatal }\end{array}$ & $\begin{array}{l}\text { exantem generalizat, cu } \\
\text { vezicule predominant } \\
\text { hemoragice, } \\
\text { cu posibilitatea } \\
\text { apariţiei unei boli } \\
\quad \text { temice }\end{array}$ & aciclovir intravenos $10-20 \mathrm{mg} / \mathrm{kg}$, de \\
\hline
\end{tabular}


pes zoster, reprezintă expunere semnificativă (10).

În cazul în care gravida nu dezvoltă exantem în urma contactului, ar trebui efectuat testul ELISA; dacă acesta este negativ (titrul imunoglobulinei $G<1: 64$ ), se presupune că gravida este susceptibilă la infecţie (11). Imunizarea (în Europa o doză i.v. de $1 \mathrm{ml} / \mathrm{kg}$ ) trebuie făcută oricând pe timpul sarcinii, în primele 96 de ore de la expunere în cazul seronegativităţii (12). Expunerea la imunoglobulină nu este cunoscută a produce risc fetal (12). În acest caz tratamentul cu aciclovir nu este indicat, iar administrarea de imunoglobulină nu poate preveni sindromul congenital de varicelă (13).

\section{VARICELA LA GRAVIDĂ}

Varicela se poate dezvolta la o gravidă seronegativă din cauza lipsei de anticorpi neutralizanţi, având de obicei o formă mai gravă decât în restul populaţiei, în special în al treilea trimestru de sarcină. Seroconversia apare în decurs de 3-4 zile de la debutul exantemului. Viaţa poate fi pusă în pericol, cu o rată a mortalităţii de $10 \%$ (14). În cazul exantemului necomplicat, se va trata cu aciclovir oral $800 \mathrm{mg}$, de 5 ori/zi. Se pare că aciclovir şi valaciclovir nu produc malformaţii genetice (15). Din cauza riscurilor la care se expun mama şi fătul, ar trebui luată în calcul operaţia cezariană.

Incidenţa varicelei este mai mică de 1-3/1.000 de sarcini, cu o rată de infectare transplacentară de $25 \%$, din care $1-2 \%$ vor manifesta clinic sindromul congenital de varicelă (16). Monitorizarea maternă şi fetală este crucială, avortul fiind recomandat doar în cazul apariţiei anomaliilor semnificative, iar riscul de avort spontan este de $8 \%(9,17,18)$.

\section{Sindromul congenital de varicelă}

În ceea ce priveşte sindromul congenital de varicelă, au fost relatate în jur de 130 de cazuri din 1947 şi până în prezent, cu o rată a mortalităţii de 30\% în primele luni de viaţă, însă cu un prognostic bun pentru supravieţuitori (19). Infecţia primară în primele două trimestre de sarcină are o incidenţă a infecţiei intrauterine de $25 \%$, iar anomaliile congenitale apar la $12 \%$ din cazuri (5). Varicela maternă în primele 20 de săptămâni de sarcină a fost asociată cu o incidenţă a sindromului congenital de varicelă de $0,91 \%$ ( 13 cazuri de sindrom congenital de varicelă la 1.423 naşteri vii) (20).
Sindromul congenital de varicelă poate include malformaţii ale mai multor sisteme sau selectiv ale unor ţesuturi sau organe (21). Pot să apară: hipoplazia membrelor (46-72\% dintre cazuri), leziuni cutanate ( $70 \%$ dintre cazuri), anomalii neurologice (48-62\% dintre cazuri), tulburări oculare (44-52\% dintre cazuri), hipoplazia musculară, întârzierea dezvoltării, anomalii ale tractului gastro-intestinal, ale tractului genitourinar şi ale sistemului cardiovascular $(10,22,23)$.

Diagnosticul prenatal se bazează pe identificarea unor semne ale comorbidităţii în urma unei examinări ultrasonografice detaliate (deformările membrelor, microcefalie, hidrocefalie, calcificarea ţesuturilor moi şi întârzierea creşterii intrauterine) (24).

Deşi rata mortalităţii în primele luni este de $30 \%$, prognosticul pe termen lung este favorabil. Nou-născuţii cu sindrom congenital de varicelă trebuie trataţi cu aciclovir intravenos pentru a preveni progresia (9).

\section{Pneumonia cu virusul varicelo-zosterian a mamei}

Incidenţa varicelei în timpul sarcinii a fost aproximată la 0,7-3/1.000 de sarcini (25). 10$20 \%$ dintre cazurile de varicelă în timpul sarcinii se complică având o rată de morbiditate/mortalitate mai mare decât în mod normal (26). Femeile gravide cu pneumonie trebuie spitalizate pentru monitorizarea şi iniţierea terapiei antivirale, deoarece până la $40 \%$ dintre ele ar putea avea nevoie de ventilaţie mecanică (27). Mortalitatea în cazurile severe este în prezent estimată la $3-14 \%(28,29)$. Riscul pentru pneumonie creşte odată cu creşterea vârstei gestaţionale.

\section{Herpes zoster la copil}

Poate să apară în primul an de viaţă dacă mama dezvoltă o infecţie primară în al doilea sau al treilea trimestru de sarcină (30). 20\% dintre descendenţi dezvoltă herpes zoster neonatal sau infantil (16). Evoluţia bolii este, de obicei, necomplicată, autolimitată, fără durere sau cu durere redusă, afectarea cutanată se remite în 10-14 zile, de obicei fără cicatrici. Analogii nucleozidici sunt utilizaţi în caz de imunosupresie, diseminare sau implicarea feţei sau a ochilor.

\section{VARICELA NEONATALĂ}

Riscul de dezvoltare a varicelei neonatale este mai mare dacă mama dezvoltă varicelă între 5 şi 7 zile prepartum şi 2 şi 7 zile postpartum, 
având o rată a mortalităţii de $7 \%(4,16,31)$. Infectarea nou-născutului se poate face prin trei căi de transmitere: transplacentar (secundar viremiei materne), ascendent (prin canalul de naştere) şi prin tractul respirator neonatal (16). Perioada de incubaţie a virusului transmis intrauterin de la începutul erupţiei materne la începutul erupţiei cutanate neonatale variază, varicela neonatală în primele 10-12 zile de viaţă fiind cauzată de transmiterea intrauterină, în timp ce după acest timp este cauzată de infecţia postnatală. Sistemul imunitar al nou-născutului este imatur şi nu a produs încă anticorpi, iar cantitatea de anticorpi materni transferată prin placentă este insuficientă din cauza timpului scurt între infecţia maternă şi naştere (4). Atunci când varicela maternă apare cu 1-4 săptămâni înainte de naştere, până la 50\% dintre nou-născuţi vor fi infectaţi, iar evoluţia bolii poate fi severă (31).

Nou născutul va dezvolta un exantem generalizat, cu vezicule predominant hemoragice, putând să apară ca o boală multisistemică gravă, incluzând pneumonie, meningoencefalită, cerebelită, mielită, hepatită, orhită, pancreatită, miocardită, nevrită nervului optic şi vasculită Henoch-Schönlein. Rata mortalităţii fără terapie este de $20-30 \%$, administrarea unei terapii adecvate reducând rata mortalităţii la $10 \%$, iar naşterea prematură <28 săptămâni de gestaţie sau greutatea mică la naştere $<1.000 \mathrm{~g}$ influenţează severitatea varicelei (32). Copiii cu antecedente de varicelă neonatală au un risc crescut de a dezvolta herpes zoster înainte de vârsta de 10 ani. Nou-născutul trebuie izolat de mamă în cazul în care are varicelă perinatal, iar copilul trebuie observat într-un cadru clinic timp de 2 săptămâni postpartum. Terapia imediată intravenoasă cu aciclovir în doză de $10-20 \mathrm{mg} / \mathrm{kg}$, de 3 ori pe zi, timp de cel puţin 7-14 zile, este esenţială.

\section{CONCLUZII}

Deşi varicela este o boală comună în copilărie, se poate dezvolta şi la adult. Mai mult, atunci când apare la femeia gravidă, este asociată cu un impact puternic negativ asupra mamei, fătului dar şi al nou-născutului. Complicaţiile - ca sindromul congenital de varicelă, pneumonia cu virusul varicelo-zosterian, varicela neonatală - pot duce la mortalitate şi morbiditate severe. Strategiile de prevenţie ar trebui să includă şi planuri de gestionare a incidenţei expunerii.

\section{Mențiune}

Toţi autorii au contribuit în mod egal la elaborarea acestei lucrări.

Conflict of interest: none declared Financial support: none declared

\section{BIBLIOGRAFIE}

1. Lamont RF, Sobel JD, Carrington $D$ et al. Varicella-zoster virus (chickenpox) infection in pregnancy. BJOG. 2011;118(10):1155-62.

2. Czumbel I, Quinten C, Lopalco P, Semenza JC. ECDC expert panel working group. Management and control of communicable diseases in schools and other child care settings: systematic review on the incubation period and period of infectiousness. BMC Infect Dis. 2018;18 (1): 199.

3. Prevention of varicella. Update recommendations of the Advisory Committee on Immunization Practices (ACIP) MMWR Recomm Rep. 1999;48(RR6):1-5.

4. Smith CK, Arvin AM. Varicella in the fetus and newborn. Semin Fetal Neonatal Med 2009;14:209-217.

5. Sauerbrei A, Wutzler P. Varicella-Zoster Virus Infections During Pregnancy: Epidemiology, Clinical Symptoms, Diagnosis, Prevention and Therapy. Current Pediatric Reviews. 2005;1:205-215.

6. Sauerbrei A, Wutzler P. Das fetale Varizellen-syndrome. Monatsschrift Kinderheilkunde. 2003;151:209-213.
7. Pastuszak AL, Levy M, Schick B, Zuber C, Feldkamp M, Gladstone J et al. Outcome after maternal varicella infection in the first 20 weeks of pregnancy. $N$ Engl J Med. 1994;330(13):901-905.

8. Miller E, Cradock-Watson JE, Ridehalgh MK. Outcome in newborn babies given anti-varicella-zoster immunoglobulin after perinatal maternal infection with varicellazoster virus. Lancet 1989; 2:371-373.

9. Marculescu R, Richter L, Rappersberger K. Infections with herpes simplex and varicella-zoster viruses during pregnancy. Hautarzt 2006; 57:207-212.

10. Daley AJ, Thorpe S, Garland SM. Varicella and the pregnant woman: prevention and management. Aust N Z J Obstet Gynaecol 2008;48:26-33.

11. Nardone A, de Ory F, Carton M et al. The comparative sero-epidemiology of varicella zoster virus in 11 countries in the European region. Vaccine 2007;25:7866-7872

12. Briggs G, Freeman R, Yaffe S. Drugs in Pregnancy and Lactation (9th ed.), Lippincott Williams \& Wilkins, Philadelphia, PA (2011)
13. Enders G, Miller E, Cradock-Watson J et al. Consequences of varicella and herpes zoster in pregnancy: prospective study of 1739 cases. Lancet 1994;343:1548-1551.

14. Chiner E, Ballester I, Betlloch I et al. Varicella-zoster virus pneumonia in an adult population: has mortality decreased? Scand J Infect Dis 2010; 42:215-221.

15. Pasternak B, Hviid A. Use of acyclovir, valacyclovir, and famciclovir in the first trimester of pregnancy and the risk of birth defects. JAMA 2010;304:859-866

16. Sauerbrei A, Wutzler P. Herpes simplex and varicella-zoster virus infections during pregnancy: current concepts of prevention, diagnosis and therapy. Part 2: Varicellazoster virus infections. Med Microbiol Immunol 2007;196:95-102.

17. Codreanu IF, Comănici VD, Stan IV et al. Rolul ecografiei în diagnosticul şi urmărirea tratamentului hemangioamelor infantile parotidiene - prezentare de caz. Practica Medicală 2018; 13,3(59):211-215.

18. Stănescu AMA, Grăjdeanu IV, Codreanu IF et al. Pregnancy associated with psoriasis - adverse outcomes and treatment. 
Romanian Journal of Maternal-Fetal and Neonatal Medicine 2018;II(2):64-67.

19. Schulze A, Dietzsch HJ. The natural history of varicella embryopathy: a 25 -year follow-up. J Pediatr. 2000;137(6):871-874.

20. Tan MP, Koren G. Chickenpox in pregnancy: revisited. Reprod Toxicol. 2006;21(4):410-420.

21. Birthistle K, Carrington D. Fetal varicella syndrome - a reappraisal of the literature. $A$ review prepared for the UK Advisory Group on Chickenpox on behalf of the British Society for the Study of Infection. J Infect. 1998;36 (Suppl 1):25-29

22. Andreou A, Basiakos H, Hatzikoumi I, manifestations limited to the eye 1. Am J Perinatol. 1995;12(5):347-348.

23. Stănescu AMA, Grăjdeanu IV, Codreanu IF et al. Dermatological emergencies in neonatology and pediatric practice.
Romanian Journal of Maternal-Fetal and Neonatal Medicine 2018;II(2):80-83.

24. Kerkering KW. Abnormal cry and intracranial calcifications: clues to the diagnosis of fetal varicella-zoster syndrome. J Perinatol. 2001;21(2):131-135.

25. Miller E, Marshall R, Vurdien J. Epidemiology, outcome and control of varicella-zoster infection. Rev Med Microbiol. 1993;4(4):222-230.

26. Gardella C, Brown ZA. Managing varicella zoster infection in pregnancy. Cleve Clin J Med. 2007;74(4):290-296.

27. Cox SM, Cunningham FG, Luby J. Management of varicella pneumonia complicating pregnancy. Am J Perinatol. 1990;7(4):300-301.

28. Harger JH, Ernest JM, Thurnau GR, Moawad A, Momirova V, Landon MB et al. Risk factors and outcome of varicella-zoster virus pneumonia in pregnant women. $J$ Infect Dis. 2002;185(4):422-427.

29. Sauerbrei A, Wutzler P. Neonatal varicella. J Perinatol. 2001;21(8):545-549.

30. Khan F, Mays R, Brooks J. Viral and sexually transmitted disease. $G$. Kroumpouzos (Ed.), Text Atlas of Obstetric Dermatology, Lippincott Williams \& Wilkins, Philadelphia, PA (2013), pp. 126-140

31. Miller E, Cradock-Watson JE, Ridehalgh MK. Outcome in newborn babies given anti-varicella-zoster immunoglobulin after perinatal maternal infection with varicellazoster virus. Lancet. 1989;2(8659):371-373

32. Akisu M, Yalaz M, Aksu G, Arslanoglu S, Genel F, Kutukculer N et al. Maternally acquired varicella-zoster virus antibodies disappear at 6 months of age in prematurely born children 1 . Panminerva Med. 2003;45(2):155-156. 